\title{
Pengembangan Kemampuan Berpikir Kritis Peserta Didik SMA dengan Lembar Kerja Proses pada Mata Pelajaran Fisika
}

\author{
${ }^{1}$ Zulfawati, ${ }^{\mathbf{2}}$ Tantri Mayasari, ${ }^{3}$ Jeffry Handhika \\ ${ }^{1,2,3}$ Prodi Pendidikan Fisika, FKIP, Universitas PGRI Madiun, Jl. Setiabudi No. 85, Kanigoro,
} Kecamatan Kartoharjo, Kota Madiun, Jawa Timur 63118

Email Korespondensi: sonyaspen.zulfa@gmail.com

\begin{tabular}{|c|c|}
\hline Article Info & lbstract \\
\hline $\begin{array}{l}\text { Article History } \\
\text { Received: } 27 \text { April } 2021 \\
\text { Revised: } 28 \text { Mei } 2021 \\
\text { Published: } 30 \text { June } 2021\end{array}$ & \multirow{2}{*}{$\begin{array}{l}\text { Student worksheets (LKPD) is the most significant aspect on the learning } \\
\text { activities because it consists of the student's learning process of gaining } \\
\text { knowledge, primarily growing the critical thinking ability. The aim of the study } \\
\text { is giving information about the development of critical thinking with LKPD } \\
\text { process in physics subject. The method is Research and Development (RnD)- } \\
\text { ADDIE which is limited on the development stage. Based on the evaluation } \\
\text { result through validity which involve expert validity from the lecturer and the } \\
\text { teacher, Content Validity Index (CVI) is } 0,95 \text { that means very suitable. The CVI } \\
\text { result indicates that the LKPD process could be used to grow the physics } \\
\text { critical thinking. The LKPD process has not arrived at implementation yet, } \\
\text { hopefully the reseacher on the same field could apply till the implementation } \\
\text { stage so that we could say LKPD process could grow the physics critical } \\
\text { thinking. }\end{array}$} \\
\hline $\begin{array}{l}\text { Keywords } \\
\text { Critical thinking skills, LKPD } \\
\text { process, physics }\end{array}$ & \\
\hline Infor & Abstrak \\
\hline $\begin{array}{l}\text { Sejarah Artikel } \\
\text { Diterima: } 27 \text { April } 2021 \\
\text { Direvisi: } 28 \text { Mei } 2021 \\
\text { Dipublikasi: } 30 \text { Juni 2021s }\end{array}$ & \multirow{2}{*}{$\begin{array}{l}\text { Lembar Kerja Peserta Didik (LKPD) menjadi aspek terpenting dalam kegiatan } \\
\text { pembelajaran karena didalamnya terdapat proses belajar peserta didik dalam } \\
\text { memperoleh pengetahuan, terutama menumbuhkan kemampuan berpikir kritis. } \\
\text { Tujuan penulisan ini yaitu memberikan informasi tentang pengembangan } \\
\text { kemampuan berpikir kritis dengan LKPD proses pada mata pelajaran fisika. } \\
\text { Metode yang digunakan yaitu Research and Development (RnD) berupa } \\
\text { ADDIE yang dibatasi pada tahapan development. Berdasarkan hasil evaluasi } \\
\text { melalui validitas yang melibatkan validitas expert dari dosen ahli serta } \\
\text { pendidik, diperoleh Conten Validity Index (CVI) sebesar 0,95 dengan kategori } \\
\text { sangat sesuai. Hasil CVI tersebut mengindikasikan bahwa LKPD proses yang } \\
\text { dikembangkan dapat digunakan untuk menumbuhkan kemampuan berpikir } \\
\text { kritis fisika. LKPD proses yang dikembangkan belum sampai pada tahap } \\
\text { implementation, diharapkan peneliti yang meneliti dibidang yang sama mampu } \\
\text { menerapkan hingga pada tahap implementation, sehingga diperoleh gambaran } \\
\text { bahwa LKPD proses mampu menumbuhkan kemampuan berpikir kritis fisika. }\end{array}$} \\
\hline $\begin{array}{l}\text { Kata kunci } \\
\text { Fisika, Kemampuan } \\
\text { berpikir kritis, LKPD } \\
\text { proses }\end{array}$ & \\
\hline & \\
\hline
\end{tabular}

\section{PENDAHULUAN}

Fisika merupakan salah satu mata pelajaran yang sangat berkaitan dengan fenomena atau kejadian di alam, karena fisika merupakan suatu ilmu yang mempelajari gejala alam (Mukti et al., 2018). Hal ini menjadikan fisika lebih mudah untuk diterapkan dalam kegiatan pembelajaran, karena fenomena yang terjadi dapat diamati secara langsung oleh peserta didik di kehidupan. Meskipun demikian tidak sedikit peserta didik yang menganggap bahwa fisika merupakan pelajaran yang susah, sehingga membutuhkan peran penting dari seorang pendidik dan media pendukung yang mampu digunakan untuk menumbuhkan tingkat pemahaman dan daya berpikir. 
Kecelakaan lalu lintas menjadi salah satu fenomena banyak dikaji karena menimbulkan kerugian baik secara material maupun psikis. Kendaraan sebagai alat transportasi yang memberikan segala kemudahan, tidak sedikit mengalami kecelakaan di jalan raya dengan berbagai penyebab. Fenomena kecelakaan yang mampu diamati secara langsung dalam kehidupan erat kaitannya dengan materi fisika momentum dan impuls. Momentum merupakan hasil kali antara massa dan kecepatan, sedangkan impuls merupakan hasil perkalian antara gaya dan selang waktu gaya bekerja, keduanya besaran vektor (Lasmi, 2012).

Keterkaitan antara kecelakaan lalu lintas dengan materi momentum dan impuls dapat diterapkan didalam kegiatan pembelajaran dengan adanya bantuan media berupa LKPD proses. Pemberian LKPD proses bertujuan untuk mengarahkan peserta didik agar dapat berinteraksi dengan berbagai sumber belajar sehingga menumbuhkan proses menemukan pengetahuan secara mandiri, mengembangkan kemampuan dalam memahami segala bentuk permasalahan maupun fenomena yang terjadi dalam kehidupan nyata dan mengembangkan kemampuan dalam berpikir kritis. Kemampuan berpikir kritis menjadi kemampuan yang harus dikembangkan dan dimiliki oleh peserta didik untuk menyongsong tantangan di abad 21. Dengan memiliki kemampuan berpikir kritis, maka akan tumbuh dalam diri peserta didik rasa peduli untuk berkontribusi menyelesaikan segala persoalan dalam kehidupan nyata. Hal ini sejalan dengan studi literatur (Retnowati et al., 2016) proses berpikir kritis sangat penting karena merupakan proses dalam menemukan informasi, menganalisis, menarik kesimpulan, mengevaluasi dan menemukan alternatif penyelesaian masalah.

Permasalahan yang kini dialami oleh pendidik maupun calon pendidik fisika media belajar LKPD yang belum teroptimalkan dalam memfasilitasi peserta didik mengembangkan kemampuan berpikir kritisnya. Berdasarkan wawancara dengan perwakilan peserta didik kelas X disalah satu Sekolah Menengah Atas di Kabupaten Wonogiri Provinsi Jawa Tengah, kegiatan pembelajaran yang berlangsung di tengah pandemi Covid-19 menggunakan buku paket yang dipinjam secara bergantian di perpustakaan sekolah. Hasil dari wawancara dengan salah seorang pendidik fisika, bahwa kegiatan pembelajaran ditengah pandemi mengoptimalkan google classroom dengan jadwal yang diserentakkan satu angkatan, hal ini cenderung menekankan aspek kognitif dengan didominasi transfer of knowledge, padahal dalam kegiatan pembelajaran sangat penting untuk transfer of value yang berguna membekali peserta didik untuk mentransferkan pengetahuannya di kehidupan sehari-hari.

Rencana pemecahan masalah ini yaitu melalui pengembangan LKPD proses yang mampu menumbuhkan kemampuan berpikir kritis fisika. Hal ini sejalan dengan studi literatur hasil penelitian (Apriyana et al., 2019) bahwa pengembangan LKS mampu meningkatkan kemampuan berpikir kritis peserta didik yang sudah teruji kevalidan, kepraktisan dan keefektifan LKS, mendapat respon positif dari peserta didik dan pendidik. Kebaruan LKPD proses yang dikembangkan yaitu adanya literasi teknologi dan rekam aktivitas belajar. Tujuan penulisan artikel memberikan gambaran pengembangan kemampuan berpikir kritis siswa SMA dengan lembar kerja proses pada mata pelajaran fisika.

\section{METODE}

Metode yang digunakan dalam pengembangan LKPD proses ini yaitu Research and Development $(R n D)$ berupa ADDIE yang terdiri dari Analysis, Design, Development, Evaluation. Pengembangan LKPD proses yang dilakukan masih terbatas sampai tahap development dan proses validasi expert namun belum melalui tahap implementation. Secara garis besar metode dalam pengembangan LKPD proses sebagaimana pada gambar 1 . 


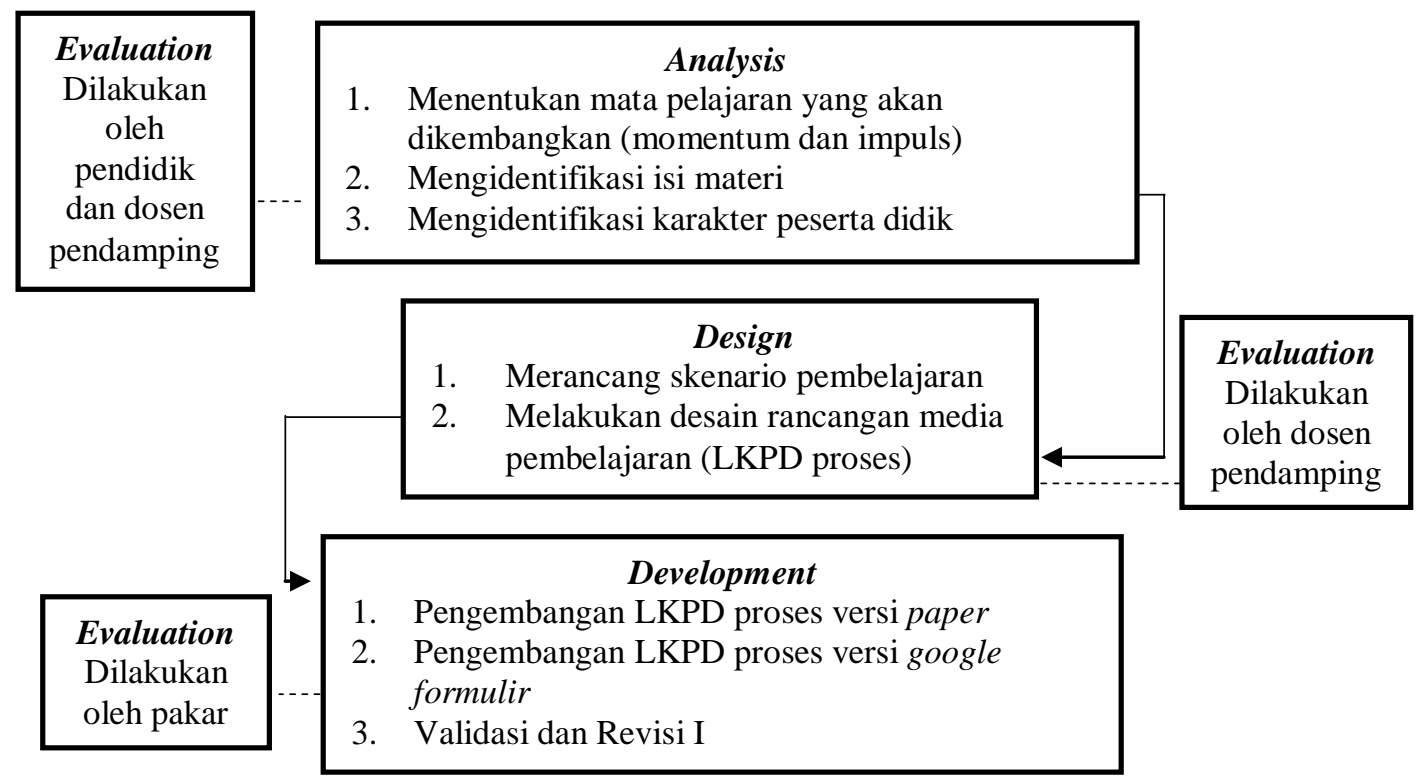

Gambar 1. Tahapan pengembangan lkpd proses

Sumber: (Cahyadi, 2019) dan pengembangan penulis

Berdasarkan gambar 1, tahapan dari pengembangan LKPD proses terdiri dari tahap analisis, tahap desain dan tahap pengembangan dimana disetiap tahapan terdapat proses evaluasi. Proses evaluasi bertujuan memberikan saran dan masukan terhadap LKPD proses yang dikembangkan.

Uji validitas yang digunakan yaitu melalui uji validitas dengan $C V I$. Dalam uji validitas ini melibatkan dosen ahli dan pendidik. Uji validitas dilakukan dengan menyebarkan angket kepada validator yang berupa pilihan YA (skor 1) dan TIDAK (skor 0). Selanjutnya dianalisis dengan menggunakan $C V R$ dan $C V I$, dimana $C V I$ merupakan rerata dari $C V R$.

$$
C V R=\frac{n e-\left(\frac{N}{2}\right)}{\frac{N}{2}}
$$

Keterangan:

Sumber: (Wardani \& Suparno, 2016)

$\begin{array}{ll}\text { CVR } & \text { : Content Validity Rasio } \\ \text { ne } & \text { : Banyaknya pakar yang menyatakan cocok } \\ \mathrm{N} & \text { : Banyaknya pakar yang memvalidasi }\end{array}$

\section{HASIL DAN PEMBAHASAN}

Hasil penulisan berupa pengembangan kemampuan berpikir kritis peserta didik melalui pengembangan LKPD proses. Sebagaimana pada tahapan pengembangan LKPD proses terbagi menjadi 3 tahapan yaitu analysis, design, development.

\section{Analysis}

Tahap analisis bertujuan untuk mengetahui mata pelajaran yang akan dikembangkan, mengidentifikasi isi materi dan mengidentifikasi karakter peserta didik. Mata pelajaran yang akan dikembangkan yaitu materi momentum dan impuls. Identifikasi isi materi bertujuan untuk mengetahui apakah materi yang akan diusung sesuai dengan permasalahan dalam kehidupan sehari-hari yang akan dikaitkan, materi momentum dan impuls dipilih karena erat kaitannya dengan permasalahan sehari-hari yang akan diusung dalam pembelajaran terkait dengan kecelakaan lalu lintas. Identifikasi karakter peserta didik bertujuan untuk mengetahui heteroginitas peserta didik. Heteroginitas peserta didik yang dimaksud adalah kemajemukan 
peserta didik baik dari segi kemampuan secara kognitif maupun tipe-tipe belajar dari peserta didik. Dari segi kemampuan secara kognitif peserta didik terbagi kedalam kemampuan tinggi, sedang, dan rendah yang dapat diketahui dari hasil penilaian kognitif berupa hasil pengerjaan tes maupun soal. Tipe-tipe belajar sangat bervariasi meliputi tipe audio, visual maupun kinestetik (Wahyuni, 2017). Audio mendengarkan, visual dengan menggunakan gambar, dan kinestetik dengan melibatkan gerak.

\section{Design}

Tahap desain bertujuan untuk merancang skenario pembelajaran dan melakukan desain rancangan media pembelajaran berupa LKPD proses. Rancangan skenario pembelajaran yang dimaksud yaitu skenario pembelajaran yang dilakukan ditengah pandemi Covid-19 dimana kegiatan pembelajaran dilakukan secara daring. Skenario ini erat kaitannya dengan desain rancangan media pembelajara LKPD proses yang akan dikembangkan. LKPD proses yang dikembangkan bertujuan untuk mengembangkan kemampuan berpikir kritis peserta didik, oleh karena itu perlu diuraikan indikator berpikir kritis yang akan dikembangkan dalam LKPD proses. Indikator berpikir kritis yang digunakan yaitu indikator berpikir kritis yang telah dikembangkan melalui kolaborasi 3 tokoh yaitu Robert H. Ennis, Mc. Lean dan Peter A. Facione, sehingga diperoleh indikator berpikir kritis sebagaimana terangkum pada tabel 1.

Tabel 1. Indikator berpikir kritis

\begin{tabular}{|c|c|c|c|}
\hline Keterangan & Robert H. Ennis & Mc. Lean & Peter A. Facione \\
\hline $\begin{array}{l}\text { Indikator } \\
\text { Berpikir Kritis }\end{array}$ & $\begin{aligned} & \square \text { Elementary Clarification } \\
& \text { (Memberikan penjelasan } \\
& \text { sederhana) } \\
& \square \text { Basic Support } \\
& \text { (membangun } \\
& \text { keterampilan dasar) } \\
& \square \text { Interfensi } \\
& \text { (menyimpulkan) } \\
& \square \text { Advanced clarification } \\
& \text { (Memberikan penjelasan } \\
& \text { lebih lanjut) } \\
& \square \text { Strategi and tactics } \\
& \text { (mengukur strategi dan } \\
& \text { taktik) }\end{aligned}$ & $\begin{array}{ll}\square & \text { Klarifikasi tesis, } \\
\text { permasalahan atau } \\
\text { pertanyaan } \\
\square \text { Membuat inferensi } \\
\text { dan interpretasi } \\
\square \text { Mendukung } \\
\text { inferensi dan } \\
\text { interpretasi } \\
\square \text { Memutuskan } \\
\text { membuat nilai }\end{array}$ & $\begin{array}{l}\square \text { Interpretasi } \\
\square \text { Analisis } \\
\square \text { Evaluasi } \\
\square \text { Inferensi } \\
\square \text { Menjelaskan } \\
\square \text { Evaluasi diri }\end{array}$ \\
\hline $\begin{array}{l}\text { Indikator } \\
\text { Berpikir Kritis } \\
\text { (Kolaborasi } \\
\text { dan } \\
\text { Pengembangan) }\end{array}$ & $\begin{array}{ll}\square & \text { Membuat dan mendukung } \\
\square & \text { Menganalisis } \\
\square & \text { Mengevaluasi secara umu } \\
\square & \text { Membuat dan mendukung } \\
\square & \text { Memberikan penjelasan s }\end{array}$ & $\begin{array}{l}\text { nterpretasi } \\
\text { dan mengevaluasi diri } \\
\text { nferensi } \\
\text { tegi dan taktik secara se }\end{array}$ & rhana dan lanjut \\
\hline
\end{tabular}

Sumber:(Ennis, 1985), (Mclean, 2005), (Facione, 2011) dan pengembangan penulis

LKPD proses yang dikembangkan untuk menumbuhkan kemampuan berpikir kritis berkaitan dengan isu permasalahan yang terjadi dalam kehidupan sehari-hari yaitu kecelakaan lalu lintas, sehingga diperlukan model pembelajaran pendukung berbasis masalah. Model yang dikembangkan yaitu model pembelajaran berbasis masalah (problem based learning). Problem based learning mereplikasi pendekatan sistematik yang banyak digunakan dalam memenuhi segala tuntutan kehidupan sehari-hari maupun dalam rangka menyelesaikan suatu permasalahan (Huda, 2013). Sintaks problem based learning yang digunakan yaitu sintaks yang telah dikembangkan melalui kolaborasi 3 tokoh yaitu DA. Kolb, Egen dan Kauchak, dan David, sehingga diperoleh indikator berpikir kritis sebagaimana terangkum pada tabel 2. 
Tabel 2. Sintaks problem based learning

\begin{tabular}{|c|c|c|c|c|}
\hline Keterangan & & DA. Kolb & Egen dan Kauchak & David \\
\hline $\begin{array}{l}\text { Sintaks problem } \\
\text { based learning }\end{array}$ & [ & $\begin{array}{l}\text { concrete experience } \\
\text { (situation analysis) } \\
\text { reflective observation } \\
\text { (problem analysis) } \\
\text { abstract } \\
\text { conceptualization } \\
\text { (solution analysis) } \\
\text { active } \\
\text { experimentation } \\
\text { (implementation } \\
\text { analysis) }\end{array}$ & $\begin{array}{l}\text { Fase } 1 \text { mereview } \\
\text { dan menyajikan } \\
\text { masalah } \\
\text { Fase } 2 \text { merancang } \\
\text { strategi } \\
\text { Fase } 3 \\
\text { menerapkan } \\
\text { strategi } \\
\text { Fase } 4 \\
\text { mendiskusikan } \\
\text { dan mengevaluasi } \\
\text { hasil }\end{array}$ & $\begin{array}{ll} & \text { Klarifikasi kata } \\
\square & \text { Merumuskan masalah } \\
\square & \text { Curah pendapat } \\
& \text { tentang hipotesa } \\
\square & \text { Penataan hipotesis } \\
\square & \text { Penetapan tujuan } \\
& \text { pembelajaran } \\
\square & \text { Pengumpulan } \\
\text { informasi dan belajar } \\
\text { mandiri } \\
\square \quad \text { Berbagi informasi dan } \\
\text { diskusi }\end{array}$ \\
\hline $\begin{array}{l}\text { Sintaks problem } \\
\text { based learning } \\
\text { (Kolaborasi } \\
\text { dan } \\
\text { Pengembangan) }\end{array}$ & $\begin{array}{l}\square \\
\square \\
\square \\
\square \\
\square\end{array}$ & $\begin{array}{l}\text { Merumuskan dan meny } \\
\text { Menganalisis masalah } \\
\text { Merancang dan menera } \\
\text { Pelaporan solusi dan re } \\
\text { Mengkaji ulang, integra }\end{array}$ & $\begin{array}{l}\text { ikan masalah } \\
\text { ran strategi solusi } \\
\text { eksi } \\
\text { i dan evaluasi }\end{array}$ & \\
\hline
\end{tabular}

Sumber: (Cockerill et al., 1996), (Egen \& Kauchak, 2012), (Sani, 2019) dan pengembangan penulis

Desain LKPD proses mengintegrasikan problem based learning guna mengembangkan kemampuan berpikir kritis. Dimana sintak, indikator, dan LKPD saling beririsan sehingga mampu beriringan dalam menumbuhkan kemampuan berpikir kritis, secara detail terangkum dalam tabel 3 .

Tabel 3. Integrasi indikator, sintak dan lkpd proses

\begin{tabular}{|c|c|c|c|c|c|}
\hline Keterangan & Tahap 1 & Tahap 2 & Tahap 3 & Tahap 4 & Tahap 5 \\
\hline $\begin{array}{l}\text { Indikator } \\
\text { Berpikir Kritis } \\
\text { (Kolaborasi dan } \\
\text { Pengembangan) }\end{array}$ & $\begin{array}{l}\text { Membuat } \\
\text { dan } \\
\text { mendukung } \\
\text { Interpretasi }\end{array}$ & Menganalisis & $\begin{array}{l}\text { Mengevaluasi } \\
\text { secara umum } \\
\text { dan } \\
\text { mengevaluasi } \\
\text { diri }\end{array}$ & $\begin{array}{l}\text { Membuat } \\
\text { dan } \\
\text { mendukung } \\
\text { Inferensi }\end{array}$ & $\begin{array}{l}\text { Memberikan } \\
\text { penjelasan } \\
\text { strategi dan } \\
\text { taktik secara } \\
\text { sederhana } \\
\text { dan lanjut }\end{array}$ \\
\hline $\begin{array}{l}\text { Sintaks problem } \\
\text { based learning } \\
\text { (Kolaborasi dan } \\
\text { Pengembangan) }\end{array}$ & $\begin{array}{l}\text { Merumuskan } \\
\text { dan } \\
\text { menyajikan } \\
\text { masalah }\end{array}$ & $\begin{array}{l}\text { Menganalisis } \\
\text { masalah }\end{array}$ & $\begin{array}{l}\text { Merancang dan } \\
\text { menerapkan } \\
\text { strategi solusi }\end{array}$ & $\begin{array}{l}\text { Pelaporan } \\
\text { solusi dan } \\
\text { refleksi }\end{array}$ & $\begin{array}{l}\text { Mengkaji } \\
\text { ulang, } \\
\text { integrasi dan } \\
\text { evaluasi }\end{array}$ \\
\hline $\begin{array}{l}\text { Pengembangan } \\
\text { LKPD proses }\end{array}$ & \multicolumn{2}{|c|}{ LKPD Breaking News } & \multicolumn{2}{|c|}{ LKPD Mind Mapping } & $\begin{array}{l}\text { LKPD } \\
\text { Simpulan }\end{array}$ \\
\hline
\end{tabular}

\section{Development}

Sumber: Pengembangan penulis

Pengembangan dilakukan dalam versi paper dan versi google formulir. Versi paper dipergunakan sebagai master yang akan dikembangkan lagi menjadi versi google formulir. Pengembangan menggunakan google formulir dipilih dengan pertimbangan untuk kegiatan belajar mengajar selama pandemi Covid-19 dilakukan secara daring, diharapkan mampu memberikan kemudahan akses bagi peserta didik. Pengembangan dari LKPD proses sebagaimana pada gambar 2 . 


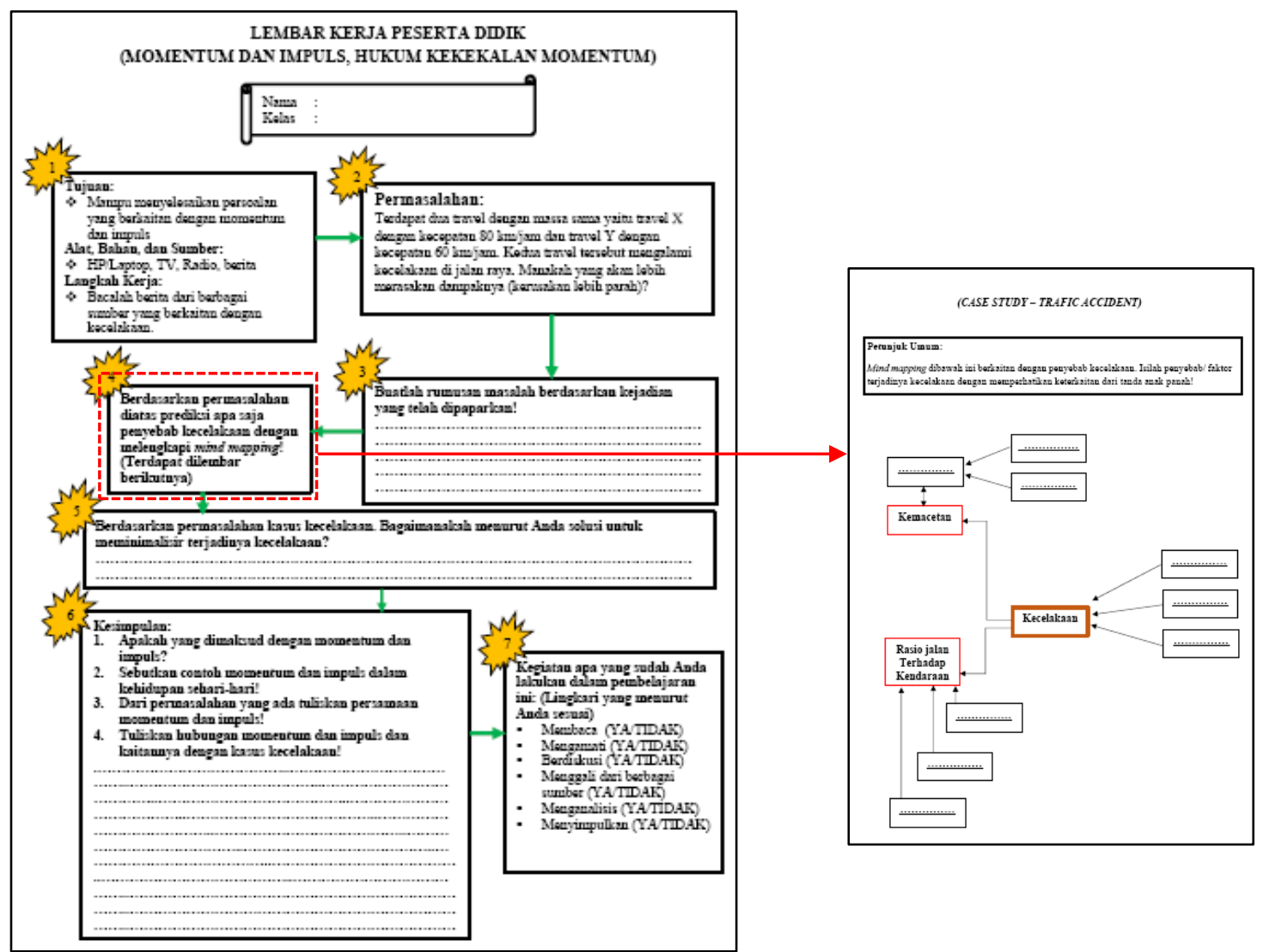

Gambar 2. Pengembangan lkpd proses versi paper

Sumber: Pengembangan penulis
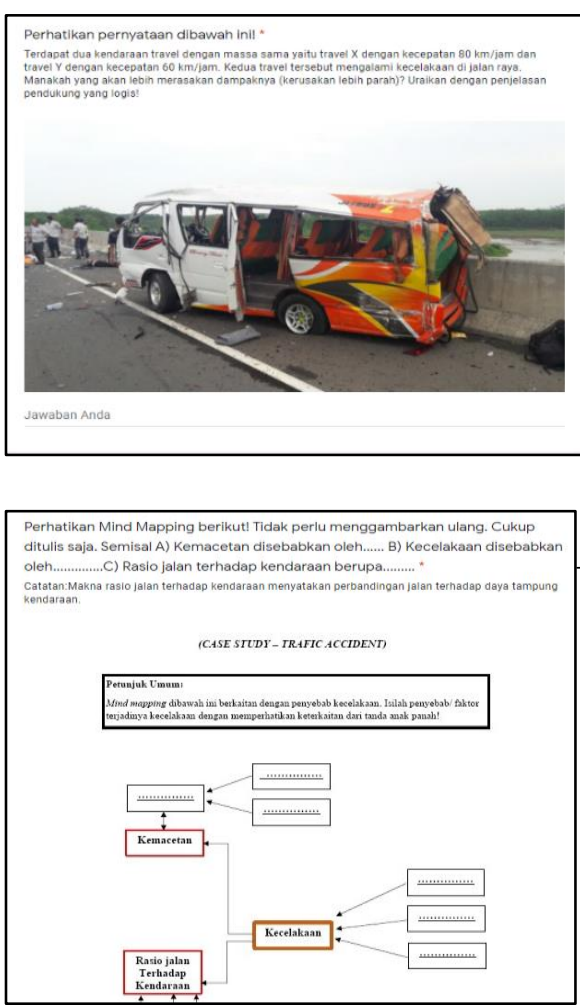


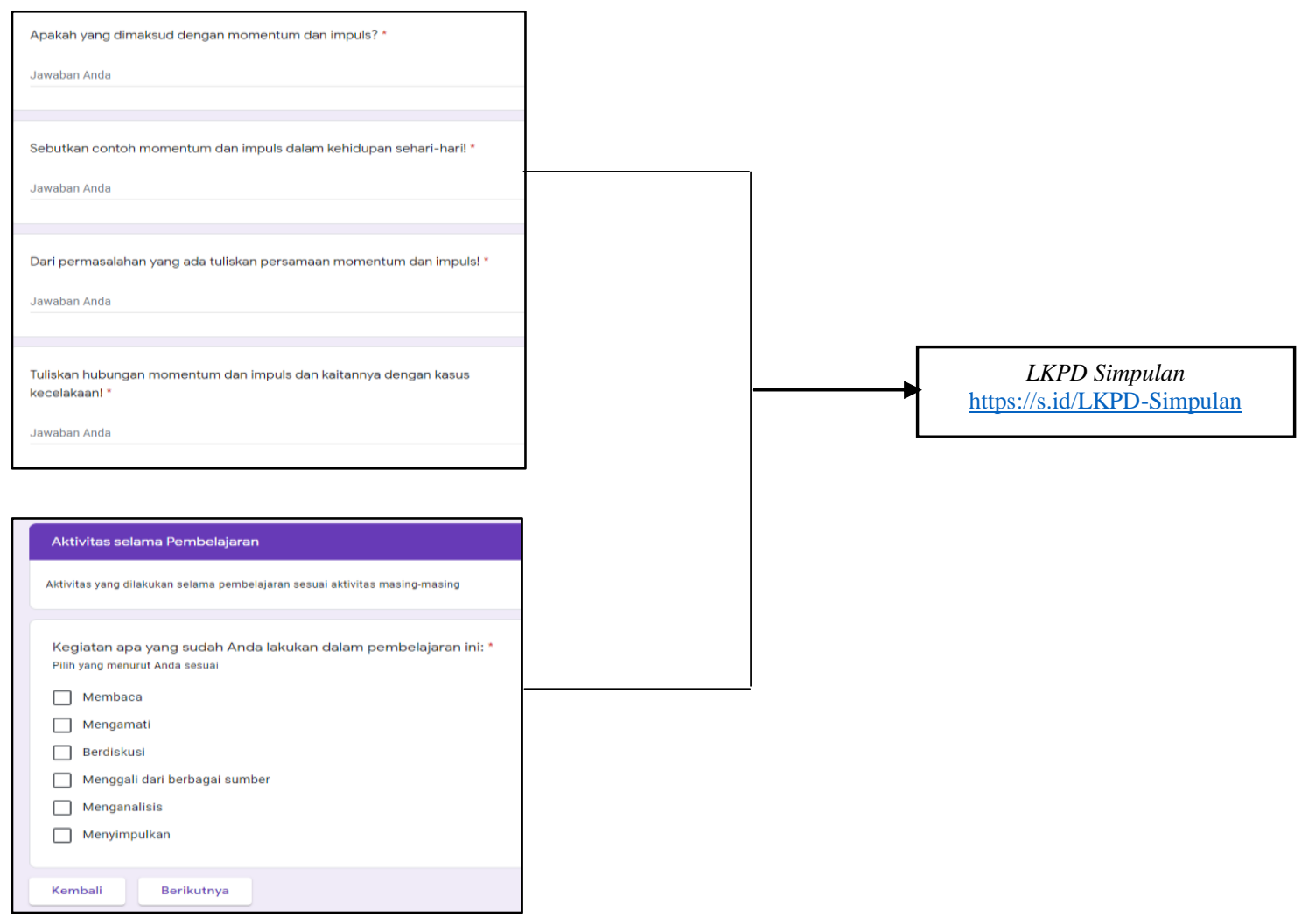

Gambar 3. Pengembangan lkpd proses versi google formulir

Berdasarkan gambar 2 dan gambar 3 pengembangan LKPD proses berbasis paper dan berbasis google formulir, LKPD proses secara umum mencakup permasalahan, mind mapping (case study-traffic accident), solusi, kesimpulan dan aktifitas belajar. Permasalahan yang diusung berkaitan dengan permasalahan real dalam kehidupan sehari-hari terkait kecelakaan lalu lintas, hal ini bertujuan untuk mengarahkan pemikiran peserta didik dalam memahami materi pembelajaran momentum dan impuls yang dikaitkan dengan permasalahan. Mind mapping (case study-traffic accident) berisi tentang penyebab kecelakaan lalu lintas, hal ini bertujuan untuk memetakan kemampuan menganalisis peserta didik menemukan penyebab kecelakaan lalu lintas ditinjau dari berbagai aspek. Pemberian mind mapping sangat penting dalam kegiatan pembelajaran, sejalan dengan studi literatur hasil penelitian (Susanti, 2016) dengan menggunakan mind mapping hasilnya lebih baik daripada metode konvensional karena melatih peserta didik memperoleh informasi, membuat jaringan topik sentral, membrainstorming, memvisualisasi, menyusun gagasan, mereview. Solusi berisi tentang pendapat peserta didik untuk menyelesaikan suatu permasalahan yang diajukan. Pemberian kolom solusi pada LKPD proses bertujuan untuk melatih peserta didik mengembangkan jiwa problem sovier ketika menghadapi suatu permasalahan. Hal ini sejalan dengan psikologi pendidikan menurut Jean Peaget peserta didik pada usia 11 tahun ke atas masuk dalam tahap operasi formal (formal operating) dimana kemampuan berpikir telah sempurna dapat berpikir deduktif dan induktif, berpikir sintesis dan analitis, serta dapat berpikir secara abstrak (Sukmadinata, 2003). Kesimpulan berisi tentang hasil dari kegiatan pembelajaran yang sudah dipelajari, hal ini berguna untuk mendorong peserta didik menyimpulkan sesuai dengan bahasa dan tingkat pemahaman masing-masing peserta didik. Aktifitas belajar didalamnya terdapat beberapa pilihan aktivitas yang harus dipilih oleh peserta didik dengan menyesuaikan kegiatan yang sudah dilakukan peserta didik selama kegiatan belajar diantaranya seperti membaca, mengamati, berdiskusi, menggali dari berbagai 
sumber, menganalisis, dan menyimpulkan. Pada aktivitas belajar menekankan pada ranah afektif khususnya aspek kejujuran, karena pembelajaran secara daring tidak dimungkinkan seluruh aktivitas belajar peserta didik tercover dan terpantau, sehingga dari sini peserta didik dilatih untuk bersikap jujur. Ranah afektif sangat penting untuk ditumbuhkan dalam kegiatan pembelajaran terkhusus pada pembelajaran daring, karena memiliki peran penting dalam menumbuhkan kepribadian.

Secara spesifik pada LKPD proses berbasis google formulir terbagi menjadi LKPD Breaking News, LKPD mind mapping, dan LKPD kesimpulan. Pada dasarnya kontennya sama hanya saja yang membedakan pada LKPD proses berbasis google formulir yaitu pemberian LKPD proses tidak serta merta diberikan secara keseluruhan kepada peserta didik, melainkan diberikan secara bertahap mengikuti alur pembelajaran. Teknis pemberian LKPD proses pada peserta didik berbasis google formulir dilakukan dengan membagikan tautan atau link yang dilanjutkan dengan proses pengisian dan proses submit untuk mengumpulkan LKPD proses yang sudah diselesaikan. Kelebihan LKPD proses berbasis google formulir karena tidak perlu melakukan print out dan mampu diakses dimanapun dan kapanpun.

LKPD proses yang dikembangkan memiliki kebaruan diantaranya yaitu adanya literasi teknologi dan rekam aktivitas belajar. Literasi teknologi yang diusung melalui google formulir, sehingga memberikan arahan kepada peserta didik untuk bersinggungan langsung dengan teknologi. Literasi teknologi penting mengingat tanpa literasi teknologi tidak akan mampu menanamkan daya kritis dalam membentuk peserta didik menjadi manusia revolusioner (Astini, 2019). Rekam aktivitas belajar bertujuan untuk mengetahui secara personal aktivitas belajar apa saja yang sudah dilakukan oleh peserta didik selama proses pembelajaran yang dilakukan secara jarak jauh dengan melakukan check list pilihan yang sudah disediakan. Aktivitas belajar yang maksimal akan menunjukkan bahwa pembelajaran berlangsung secara baik dan optimal, sehingga pembelajaran menjadi berkualitas (Mulyadi et al., 2016).

LKPD proses sudah melalui tahap validasi untuk mengetahui tingkat kevalidan dari LKPD proses yang dikembangkan. Validasi melibatkan 7 validator yang terdiri dari dosen ahli dan pendidik yang bersangkutan. Hasil validasi sebagaimana pada tabel 1.

Tabel 1. Hasil validasi lkpd proses

\begin{tabular}{lcc}
\hline \multicolumn{1}{c}{ Aspek Penilaian } & Skor Validitas & Kriteria \\
\hline Syarat Didaktik & 1,000 & Sangat Sesuai \\
Syarat Konstruksi & 0,943 & Sangat Sesuai \\
Syarat Teknis & 1,000 & Sangat Sesuai \\
Kemunculan Karakteristik Science Edutaiment & 0,857 & Sangat Sesuai \\
Rata-Rata & $\mathbf{0 , 9 5 0}$ & Sangat Sesuai \\
\hline
\end{tabular}

Berdasarkan tabel 1, aspek penilaian mencakup syarat didaktik, syarat konstruksi, syarat teknis, dan kemunculan science edutaiment. Hasil analisis dari CVI sebesar 0,95 dengan kategori sangat sesuai, sehingga LKPD proses yang dikembangkan dapat dipergunakan untuk kegiatan pembelajaran dalam rangka menumbuhkan kemampuan berpikir kritis fisika peserta didik dengan membutuhkan sedikit perbaikan. Revisi yang diberikan oleh validator bertujuan untuk memberikan perbaikan terhadap instrumen LKPD proses yang dikembangkan. Revisi dari validator yaitu agar menambahkan gambar pendukung dari LKPD proses yang dikembangkan, sehingga peserta didik tidak mengalami kesulitan saat memahami LKPD proses.

LKPD proses yang telah dikembangkan memiliki kekuatan dan peluang. Kekuatan terletak pada berbasis permasalahan langsung dalam kehidupan sehari-hari sehingga mudah bagi peserta didik untuk memahami dan mengkaitkan dengan materi. Pembelajaran berbasis masalah berkaitan dengan penggunaan intelegensi untuk memecahkan masalah yang relevan 
dan kontekstual (Rusman, 2014). Peluang terletak pada integrasi dengan teknologi, hal ini dikarenakan dengan adanya integrasi teknologi mampu memberikan kemudahan akses bagi peserta didik. Sejalan dengan pendapat (Fitriyadi, 2013) bahwa peluang mengintegrasikan teknologi dalam pembelajaran diantaranya: a) aktivitas belajar fleksibel yang nyaman bagi peserta didik, b) meningkat efisiensi, pelayanan dan mengurangi biaya, c) dapat menampilkan kekayaan data tentang kemajuan belajar dan kinerja peserta didik. Melalui kekuatan dan peluang, maka pengembangan LKPD proses secara umum mampu memfasilitasi belajar peserta didik dalam mengembangkan kemampuan berpikir kritis.

\section{KESIMPULAN}

Berdasarkan pembahasan yang telah disajikan dapat disimpulkan pengembangan kemampuan berpikir kritis peserta didik SMA dengan menggunakan LKPD proses dikembangkan melalui paper dan google formulir yang sudah tervalidasi dengan CVI sebesar 0,95 dengan kategori sangat sesuai. Pengembangan tahap google formulir dilakukan dengan menyesuaikan kegiatan pembelajaran yang dilakukan secara daring ditengah pandemi Covid-19 dengan mengintegrasikan indikator berpikir kritis, sintaks problem based learning pada pengembangan LKPD proses.

\section{SARAN}

Pengembangan LKPD proses yang dilakukan baru sampai tahap development, bagi peneliti dibidang yang sama diharapkan kedepannya mampu mengembangkan hingga tahap implementation sehingga terlihat gambaran maupun sebaran kemampuan berpikir peserta didik dengan menggunakan LKPD proses yang telah dikembangkan. Bagi pendidik perlu memperhatikan karakter dan kemampuan awal berpikir kritis masing-masing peserta didik sehingga memiliki rancangan mengembangkan kemampuan berpikir kritis sesuai kemampuan awal yang dimiliki. Bagi peserta didik sangat penting untuk mengikuti alur pembelajaran karena didalamnya terdapat serangkairan sintaks dan indikator yang harus dikembangkan.

\section{DAFTAR PUSTAKA}

Apriyana, N., Herlina, K., \& Abdurrahman, A. (2019). Pengembangan Lembar Kerja Siswa Berbasis Inkuiri Terbimbing untuk Meningkatkan Kemampuan Berpikir Kritis. Jurnal Pendidikan Fisika, 7(2), 92-96.

Astini, N. K. S. (2019). Pentingnya Literasi Teknologi Informasi Dan Komunikasi Bagi Guru Sekolah Dasar Untuk Menyiapkan Generasi Milenial. Prosiding Seminar Nasional Dharma Acarya, 1(2018), 113-120.

Cahyadi, R. A. H. (2019). Pengembangan Bahan Ajar Berbasis Addie Model. Halaqa: Islamic Education Journal, 3(1), 35-43. https://doi.org/10.21070/halaqa.v3i1.2124

Cockerill, S., Douglas, J., Gold, J., Stewart, G., \& Hamilton, L. (1996). The international management of change : a learning / case study approach. Jurnal Education = Training, $38(2), 14-17$.

Egen, P., \& Kauchak, D. (2012). Strategie and Models for Teachers: Teaching Content and Thinking Skills (6 ed.). Boston: Pearson Education.

Ennis, R. H. (1985). A Logical Basis for Measuring Critical Thinking Skills. In Educational Leadership. https://pdfs.semanticscholar.org/80a7/c7d4a98987590751df4b1bd9adf747fd7aaa.pdf

Facione, P. a. (2011). Critical Thinking: What It Is and Why It Counts. In Insight assessment (Issue ISBN 13: 978-1-891557-07-1.). https://www.insightassessment.com/CTResources/Teaching-For-and-About-Critical-Thinking/Critical-Thinking-What-It-Isand-Why-It-Counts/Critical-Thinking-What-It-Is-and-Why-It-Counts-PDF

Fitriyadi, H. (2013). Integrasi Teknologi Informasi Komunikasi Dalam Pendidikan : Potensi Manfaat, Masyarakat Berbasis Pengetahuan, Pendidikan Nilai, Strategi Implementasi 
Dan Pengembangan Profesional. Jurnal Pendidikan Teknologi Dan Kejuruan, 21(3), 269-284.

Huda, M. (2013). Model-Model Pengajaran dan Pembelajaran. Yogyakarta: Pustaka Belajar. Lasmi, N. K. (2012). SPM Fisika SMA dan MA Siap Tuntas Menghadapi Ujian Nasional. Bandung: Esis.

Mclean, C. L. (2005). Evaluating Critical Thinking Skills : Two Conceptualizations. Journal of Distance Education Revue de L'Education a Distance Spring/Printemps, 20(2), 120.

Mukti, F., Connie, C., \& Medriati, R. (2018). Pengembangan Lembar Kerja Peserta Didik (LKPD) Pembelajaran Fisika untuk Meningkatkan Kemampuan Berpikir Kreatif Siswa SMA Sint Carolus Kota Bengkulu. Jurnal Kumparan Fisika, 1(3), 57-63. https://doi.org/10.33369/jkf.1.3.57-63

Mulyadi, M., Wakhinuddin, W., \& Fernandez, D. (2016). Meningkatkan Aktivitas Belajar Siswa Dengan Menggunakan Cooperative Learning Type Stad Pada Mata Pelajaran Dasar Otomotif Kelas X Otomotif Di Smk N 1 Sumbar. Jurusan Teknik Otomotif FT UNP, 9(10), 1-10.

Retnowati, D., Sujadi, I., \& Subanti, S. (2016). Proses Berpikir Kritis Siswa Kelas XI Farmasi SMK Citra Medika Sragen dalam Pemecahan Masalah Matematika. Jurnal Elektronik Pembelajaran Matematika, 4(1), 105-116.

Rusman, R. (2014). Penerapan Pembelajaran Berbasis Masalah. Edutech, 13(2), 211. https://doi.org/10.17509/edutech.v13i2.3102

Sani, R. A. (2019). Pembelajaran Berbasis HOTS (Higher Order Thinking Skills) (1 ed.). Tangerang: Tira Smart.

Sukmadinata, N. S. (2003). Landasan Psikologi Proses Pendidikan (1 ed.). Bandung: PT Remaja Rosdakarya.

Susanti, S. (2016). Metode Mind Mapping Untuk Meningkatkan Hasil Belajar Ips Di Sekolah Dasar. Jurnal Pendidikan Guru Sekolah Dasar, 1(1), 25-37. https://doi.org/10.17509/jpgsd.v1i1.9060

Wahyuni, Y. (2017). Identifikasi Gaya Belajar ( Visual, Auditorial , Kinestetik) Mahasiswa Pendidikan Matematika Universitas Bung Hatta. Jppm, 10(2), 128-132. https://jurnal.untirta.ac.id/index.php/JPPM/article/view/2037

Wardani, M. I., \& Suparno, S. (2016). Pengembangan Sistem Assessment Pembelajaran Materi Dinamika Partikel Berbasis Media Audio Visual Di Sma N 1 Pakem. Jurnal Pendidikan Fisika, 5(5), 329-336. 